\title{
PENERAPAN SISTEM NILAI DALAM BUDAYA ORGANISASI SEKOLAH UNGGUL: STUDI MULTIKASUS
}

\author{
Manshur \\ Universitas PGRI Banyuwangi (email: sakila_advbwi@yahoo.com)
}

\begin{abstract}
Abstrak: Penerapan Sistem Nilai dalam Budaya Organisasi Sekolah Unggul Studi Multikasus. Tujuan penelitian ini adalah memperoleh gambaran mendalam tentang penerapan sistem nilai dalam budaya sekolah unggul yang memiliki latar budaya organisasi yang berbeda, baik dari segi nilai-nilai yang dianut maupun penyelenggaranya, yaitu SMPN1 Banyuwangi, SMP Kristen Aletheia Genteng, dan SMP Bustanul Makmur Genteng. Penelitian ini menggunakan pendekatan kualitatif dengan rancangan studi multikasus dengan menggunakan pendekatan fenomenologis dan budaya. Informan ditetapkan secara purposif. Teknik pengumpulan data meliputi wawancara mendalam, observasi partisipan, dan studi dokumentasi. Data dianalisis secara berulang-ulang melalui analisis dalam kasus dan analisis lintas kasus. Temuan penelitian sebagai berikut. (1) Penerapan sistem nilai pengetahuan terwujud apabila (a) terlaksana sistem nilai prestasi; (b) sistem nilai mandiri; (c) sistem nilai displin; dan (d) sistem nilai keunggulan. (2) Penerapan sistem nilai sosial terwujud apabila (a) terlaksana sistem nilai kebebasan yang ber tanggung jawab; (b) sistem nilai kesederhanaan kesahajaan; dan (c) sistem nilai kebersamaan dan persaudaraan. (3) Penerapan sistem nilai agama terwujud apabila (a) terlaksana sistem nilai ibadah; dan (b) sistem nilai kerendahan hati.
\end{abstract}

Kata Kunci: sistem nilai, budaya organisasi, sekolah unggul, SMP

\begin{abstract}
The Implemetation of Value Systems in the School of Organizational Culture Leading Multi-Case Study. The purpose of this research is to gain an indepth exploration of the value systems in a superior school's culture that are set in different organizational cultures, both in terms of the values espoused and the organizers, namely SMPN1 Banyuwangi, SMP Christian aletheia Genteng and SMP Makmur Bustanul Genteng. This study used a qualitative approach with a multicase study design using a phenomenological approach and culture. Informant set purposively. Data collection techniques include in-depth interviews, participant observation, and study documentation. Data were analyzed repeatedly through the analysis in the case and cross-case analysis. The findings of the study is as follows.

(1) The implementation of the value systems of knowledge will be achieved if (a) performance value systems are realized; (b) the independent value systems; (c) the discipline value systems; (d) the excellence value systems. (2) The implementation of the social values systems will be achieved if (a) the responsibility freedom value systems is implemented; (b) the simplicity modesty value systems; (c) the together-
\end{abstract}


ness and brotherhood values systems. (3) The provision of religious values will be achieved if (a) Worship value systems are realized; and (b) the humility value.

Keywords: value systems, organizational culture, superior schools, junior high schools

\section{PENDAHULUAN}

Pada era kompetisi global, program peningkatan kualitas sumberdaya manusia menjadi prioritas utama di hampir semua negara dalam usaha mensejahterakan masyarakat. Kualitas sumberdaya manusia sangat terkait dengan kualitas pendidikan yang merupakan produk dari lembaga pendidikan atau sekolah. Namun, pada kenyataannya menurut Alam (2006:3), dunia pendidikan kita saat ini dihadapkan berbagai persoalan rumit dan kompleks, di antaranya kualitas kinerja pengelolaan pendidikan ke depan yang masih patut dipertanyakan; rendahnya kualitas akademis hampir pada semua jenjang pendidikan (disebabkan karena masih rendahnya kualitas guru, pengawas, dan kepala sekolah secara rerata); rendahnya mutu birokrasi pendidikan pada hampir semua unit dan tingkatan; serta masih terbatasnya dana pendidikan yang dapat digunakan untuk mendorong pemerataandan peningkatan kualitas pendidikan. Kondisi ini tidak terlepas dari fenomena yang ada di tengah-tengah masyarakat, yaitu tuntutan masyarakat terhadap pendidikan yang berkualitas dan berlatar nilai terus meningkat. Faktor yang menuntut setiap lembaga pendidikan untuk terus-menerus meningkatkan kualitas input, proses dan out put pendidikan ada tiga hal, yaitu (1) faktor tantangan di era global; (2) ke- sadaran orang tua akan pendidikan yang berkualitas; dan (3) kenakalan remaja yang di sebabkan menipisnya jati diri.

Tantangan di era global merupakan fenomena yang tidak bisa dihindari karena pasti akan datang/terjadi dan harus dihadapi. Oleh karena itu, setiap negara harus menjadi bagian dari fenomena itu. Para pakar seperti Hasnan Habib, dkk, yang telah menekuni masalah globalisassi menjelaskan bahwa sekarang era global telah berjalan dan mempegaruhi berbagai sektor kehidupan (Sutarmadi,1997:6). Persaingan global dalam pasar bebas menyebabkan adanya kompetisi yang sangat ketat, bukan saja produk barang dan jasa, namun juga kualitas SDM.

Untuk dapat berpartisipasi dalam kancah tersebut, setiap bangsa dituntut memiliki SDM yang berkualitas, tidak saja mengoptimalkan pendayagunaan sumberdaya alam serta teknologi yang ada, namun juga dapat menjalin kerja sama antarbangsa. Setiap personal dituntut memiliki keuletan, kedisiplinan, dan etos kerja yang tinggi, pandai menangkap peluang serta memiliki semangat untuk terus belajar (Suryadi, 1998). Dengan kata lain, masalah kualitas SDM sesungguhnya tidak hanya diukur dengan pendidikan atau penguasaan keterampilan semata, namun juga memiliki mental atau etos-etos, terutama etos ke- 
ilmuan dan etos kerja, di samping etosetos lainnya.

Kesadaran dan tuntutan terhadap pendidikan yang berkualitas merupakan kebutuhan yang tidak bisa ditundatunda lagi karena orang tua telah memiliki kesadaran ekonomis bahwa pendidikan adalah sebuah investasi bagi diri dan anak mereka. Selain itu, orang tua juga telah menyadari bahwa pendidikan merupakan "industri jasa". Oleh karena itu, sebagai customer, kata Sallis, mereka berhak meminta layanan yang berkualitas (Ekosusilo, 2003).

Pemberitaan diberbagai media yang memuat kenakalan anak-anak remaja, guru terkena pelanggaran norma dan etika karena lemahnya jati diri, seperti minuman keras,narkoba, pelecehan seksual, trifiking, ataupun tindak kriminal seperti pencurian, tawuran, perampokan, pembunuhan, dan sebagainya. Oleh karena itu, pendidikan harus dilandasi oleh nilai moral, sistem moral etis dalam segala perilaku (Madjid, 1997). Hal yang cukup mencengangkan berdasarkan data Komisi Nasioanal Perlindungan Anak disebutkan bahwa perilaku seksual remaja SMP dan SMA di Indonesia sudah mencapai angka menghawatirkan: 93,7\% mengaku pernah berciuman; 64\% remaja SMU sudah tidak perawan, dan 30\% remaja seusia SMA telah melakukan aborsi.

Sistem nilai merupakan keinginan afektif, kesadaran yang membimbing perilaku, diwariskan dari satu generasi kegenerasi berikutnya dan di komunikasikan melalui pendidikan, agama, keluarga, komunitas, dan organisasi (Ivancevich, et al., 2005:42). Sistem nilai adalah keseluruhan konsep yang saling berhubungandan saling mempengaruhi tentang ukuran baik buruk berdasarkan keyakinan tertentu.

Budaya organisasi adalah apa yang dipersepsikan orang dalam organisasi, dan cara pandang/persepsi itu menciptakan suatu pola keyakinan, nilai, dan ekspektasi. MenurutEdgar Schein (Ivancevich, et al., 2005:44), budaya organisasi sebagai suatu pola dasar yang diciptakan, ditemukan, dan dikembangkan oleh kelompok tertentu saat belajar menghadapi masalah adaptasi eksternal dan integrasi internal yang telah berjalan cukup baik untuk dianggap valid. Oleh karena itu, perlu diajarkan kepada anggota baru sebagai cara yang benar untuk berpersepsi, berpikir, dan berperasaan sehubungan dengan masalah yang dihadapi.

Sekolah unggul adalah sekolah yang dikembangkan untuk mencapai keunggulan dalam keluaran (output) pendidikan. Untuk mencapai keunggulan tersebut, masukan (input), proses pendidikan guru dan tenaga kependidikan, manajemen, layanan pendidikan, serta sarana penunjang harus diarahkan untuk menunjang tercapainya tujuan tersebut. (Depdikbud, 1994).

Berdasarkan latar belakang inilah, peneliti tertarik untuk meneliti keunggulan sekolah dari dimensi soft, yaitu sesuatu yang tidak mudah diukur, berupa sistem nilai dalam budaya sekolah pada sekolah-sekolah unggul sekaligus yang menyebabkan terwujudnya iklim sekolah yang aman dan nyaman. Selain itu, juga ingin melihat lebih jauh dan mendalam pendapat (Owens, 1995:81) yang menyatakan bahwa dimensi soft, yang mencakup nilai-nilai (values), ke- 
yakinan (beliefs), budaya, norma perilaku justru lebih berpengaruh terhadap kinerja individu dan organisasi sehingga (sekolah) menjadi unggul.

\section{METODE}

Penelitian ini menggunakan pendekatan kualitatif dengan rancangan studi multikasus. Orientasi yang digunakan pendekatan fenomenologis dan pendekatan budaya, informan ditetapkan secara purposif. Penelitian ini diharapkan dapat mendeskripsikan secara menyeluruh dan utuh mengenai penerapan sistem nilai dalam budaya organisasi sekolah unggul yang berhubungan dengan pengetahuan, sosial, dan agama. Bogdan dan Biklen (1998:62) menegaskan, "When researchers study two or-more subjects, settings, or depositories of data they are usually doing what we call multicase studies. Multi case studies take a variety of forms." Karakteristik utama studi multikasus adalah apabila peneliti meneliti dua atau lebih subjek latar atau tempat penyimpanan data.

Kasus yang diteliti adalah penerapan sistem nilai dalam budaya organisasi sekolah unggul yang memiliki latar berbeda, seperti berikut. (1) SMPN 1 Banyuwangi di bawah pembinaan dinas pendidikan yang aturan pengelolaannya mengacu pada aturan dari pemerintah. (2) SMP Kristen Aletheia di bawah Yayasan Kristen Aletheia Genteng, pengelolaannya mengacu pada peraturan yang berlaku secara umum dari pemerintah, juga berkewajiban mengikuti aturan khusus yang ditentukan oleh Yayasan Aletheia.(3)SMP Bustanul Makmur di bawah Yayasan Pendidikan Bustanul Makmur, pengelolaannya me- ngikuti aturan umum dari pemerintah, juga harus mengikuti aturan yang telah ditentukan oleh Yayasan PP Bustanul Makmur.

Rancangan studi multikasus dilakukan sebagai upaya pertanggungjawaban ilmiah berkenaan dengan kaitan logis antara fokus penelitian, pengumpulan data yang relevan, dan analisis data hasil penelitian. Penerapan rancangan studi multikasus dimulai dari kasus tunggal (sebagai kasus pertama) terlebih dahulu, kemudian dilanjutkan pada kasus kedua dan ketiga. Teknik pengumpulan data meliputi: (1) wawancara mendalam; (2) observasi partisipan; dan (3) studi dokumentasi. Data yang terkumpul melalui ketiga teknik tersebut diorganisasir, ditafsir, dan dianalisis secara berulang-ulang melalui analisis dalam kasus maupun analisis lintas kasus guna menyusun konsep dan abstraksi temuan penelitian.

\section{HASIL}

Penelitian ini menghasilkan beberapa temuan sebagai berikut. Pertama, penerapan sistem nilai pengetahuan. (1) Untuk mencapai prestasi dapat terwujud apabila: (a) v:isi misi sekolah terealisasir ke dalam RKAS dan RKS serta memotivasi seluruh kegiatan pembelajaran; (b) PBM yang dilaksanakan merupakan realisasi dari program sekolah yang tertuang dalam RKS dan buku dokumen kurikulum serta pedoman mutu; (c) PBM didukung oleh kualitas SDM yang memadai, sarana prasarana yang cukup dan input yang selektif; (d) PBM terlaksana dalam iklim yang kondusif, menyenangkan, serta dukungan wali murid, peran paguyuban kelas, 
serta komite sekolah. (2) Untuk menumbuhkan semangat mandiri, dapat terwujud apabila: (a) siswa diberi kebebasan dan dipacu untuk mengembangkan potensi, meningkatkan nilai, baik secara individu atau kelompok; (b) peran guru sebagai motivator dan fasilitator; (c) adanya budaya jujur; (d) adanya reward dan sanksi. (3) Untuk membentuk disiplin, dapat terwujud apabila: (a) adanya aturan yang lengkap/utuh, membudaya, disepakati oleh semua fihak: siswa, guru, karyawan maupun komite/ yayasan; (b) kesadaran semua fihak untuk melaksanakan aturan yang telah disepakati bersama; dan (c) dukungan keyakinan agamanya masing-masing. (4) Untuk mencapai keunggulan dapat terwujud apabila: (a) keunggulan merupakan kebutuhan dan tanggung jawab seluruh warga, siswa, orang tua dan guru; (b) siswa baru ditekankan harus siap belajar melebihi siswa lain; (c) belajar intensif utamanya untuk mata pelajaran MIPA dan bahasa Inggris/Arab di lingkungan siswa dan guru; (d) sejarah positif sekolah, dukungan alumni, penghargaan terhadap eksistensi sekolah, rujukan studi banding dengan sejarah positif sekolah, dukungan alumni, penghargaan eksistensi sekolah dan rujukan studi banding akan memberi sugesti dan semangat untuk unggul; dan (e) program paket aplikasi sekolah (PAS) memberi kemudahan orang tua untuk memantau nilai anak melalui sms.

Kedua, penerapan sistem nilai social.

(1) Kebebasan dapat terwujud apabila: (a) terlaksana kebebasan berpendapat, berkreasi, berekspresi, menyampaikan kritik seperti agenda polling oleh OSIS; (b) kegiatan poling adalah murni inisiatif dan tanggung jawab siswa; dan (c) menghargai keberagamanan dengan anggapan hidup ini adalah majmuk. (2) Kesederhanaan dan kesahajaan dapat terwujud apabila: (a) PSB lewat seleksi; (b) peduli sosial, simpati dan mengajarkan pola hidup sederhana; dan (c) pelarangan memakai HP serta perhiasan menyolok bagi siswa perempuan. (3) Kebersamaan dan persaudaraan dapat terwujud apabila: (a) sikap saling tolong, saling bantu, telah mewarnai seluruh kegiatan kesiswaan, keagamaan \& kemasyarakatan; (b) terjalin rasa saling menghormati, menyayangi antar sesama, adik, dan kakak kelas; dan (c) kesetaraan merentas keberagaman dan kebersamaan adalah visi sekolah.

Ketiga, penerapan sistem nilai agama. (1) Sistem nilai ibadah dapat terwujud apabil: (a) sebelum pelajaran didahului dengan kegiatan ibadah sholat dhuha, baca kitab suci, renungan pagi, membiasakan dan menyadarkan makna hidup; (b) pelajaran dimulai dengan salam, dan do'a, memohon rahmat kepada Yang Maha Kuasa agar usahanya diridho'i dan mendapat kesuksesan. (2) Setelah PBM dan evaluasi, diakhiri dengan do'a, salam agar hasil belajarnya bisa sempurna, bermanfaat, selamat sampai rumah; (c) kegiatan ibadah dapat meningkatkan keimanan dan ketaqwaan kepada Tuhan Yang Maha Kuasa. (3) Kerendahan hati/tawaddu' dapat terwujud apabila: (a) meletakkan nilai moral pada porsi penentuan kenaikan kelas dan kriteria kelulusan; (b) adanya penghormatan dan penyambutan siswa; (c) ajaran taqwa, jabat tangan, taat pada pimpinan, dan tunduk terhadap kehen- 
dak Tuhan menjadikan siswa santun dan rendah hati; dan (d) dibekali training kecerdasan, diajarkan hakikat dan makna hidup, iman yang kuat achlak terpuji, dan rendah hati agar mampu menghadapi ujian hidup dengan sabar dan tawakkal.

\section{PEMBAHASAN}

Segenap aktivitas manusia hakikatnya adalah penerapan dari apa yang diyakini dan melandasi seluruh aspek hidupnya. Alisyahbana (1986) mengemukakan bahwa nilai-nilai ialah sesuatu yang diakui orang berdasarkan perasaan sebagai sesuatu yang tersusun rapi. Orang dapat berbuat terhadap nilai dengan jalan memikirkan, mengakui, menghargai, dan mendorongnya. Dalam kehidupan individu dan masyarakat, nilai-nilai merupakan tenaga pendorong dan pemberi arah dari perilaku individu dan masyarakat. Nilai-nilai merupakan sesuatu yang tidak dapat ditangkap begitu saja secara kebetulan, melainkan diperoleh oleh seseorang melalui proses indrawi (dorongan hidup dan insting), kata hati (hati nurani), dan rasio (akal). Siagian (1989) menyebutkan 4 macam sumber nilai bagi seseorang, yaitu: (1) orang tua; (2) masyarakat; termasuk lembaga pendidikan; (3) teman bergaul; dan (4) diri sendiri melalui perjalanan pengalaman dan akalnya.

Kepribadian seseorang pada hakikatnya ditentukan oleh nilai-nilai yang terintegrasi dalam dirinya sehingga mendorong untuk berbuat atau melakukan sesuatu. Tindakan atau perbuatan seseorang mencerminkan nilai-nilai yang diakui dan dianutnya. Nilai-nilai meng- arahkan jalan hidup seseorang. Seseorang bertindak berdasarkan nilai yang diyakini, dan selalu diulang sehingga menjadi kaidah hidupnya (Sastrapratedja dalam Kaswardi, 1993). Nilai-nilai merupakan kenyataan yang tersembunyi di balik kenyataan lain. Dengan kata lain, kenyataan lain merupakan pembawa nilai seperti halnya suatu benda menjadipewarna bagi benda lain. Nilainilai itu ada, akan tetapi untuk mengetahui atau melacaknya, harus melalui pelacakan terhadap kenyataan-kenyataan lain, seperti tindakan, pola tingkah laku, berpikir dan sikap dari seseorang atau sekelompok orang (Kadarusmadi, 1996).

Sistem nilai prestasi sudah menjadi komitmen seluruh keluarga sekolah, dan sekolah sudah bertekad melaksanakan sesuai latar masing-masing, penerapannya sesuai dengan karakter masing-masing sebagaimana dalam budaya organisasi. Owens (1995:82) mendefinisikan, "The body of solution to external and internal problems that has worked consistently for a group and that is therefore taught to new members as the correct way to perceive, think about and feel in relation to those problem." (pola pemecahan masalah eksternal dan internal yang ditekankan secara konsisten bagi suatu kelompok, dan oleh karenanya diajarkan kepada anggota-anggota baru sebagai cara yang benar dalam memandang, memikirkan dan merasakan masalah yang dihadapi tersebut).

Sinarmo (1998:4) menegaskan bahwa secara ringkas, visi adalah apa yang didambakan organisasi untuk "dimiliki" atau diperoleh di masa depan (what do we want to have). Misi adalah dambaan 
tentang kita ini akan "menjadi" apa di masa depan (what do we want to be). Agar efektif dan powerful, visi dan misi harus jelas, harmonis, dan kompatibel. Visi bukan sekedar penglihatan kasat mata, melainkan penglihatan dengan kekuatan mental atau dengan kacamata batin dalam arti kognitif, afektif dan psikomotorik. Visi dibentuk dengan kecerdasan umum, penghayatan nilai-nilai, pengetahuan dan pengalaman, kemampuan-kemampuan dalam bidang khusus secara konseptual, pemecahan masalah, dan daya keperilakuan lain yang dijadikan unggulan. Dalam pengertian ini, visi merupakan saripati endapan dari sistem nilai dan kaidahkaidah, antara lain: dorongan visi misi sekolah, visi misi sekolah terwujudnya keunggulan prestasi, kualitas lulusan yang handal/unggul, keunggulan intelektual, spiritual dan berdaya saing global.

Sistem nilai kebebasan dan kemandirian untuk mengembangkan potensi, meningkatkan grade nilai, budaya jujur, reward, guru sebagai motivator dan fasilitator, kelompok kerja berperan meningkatkan prestasi. Sistem nilai mandiri diartikan sebagai kecerdasan yang mendapat inspirasi, dorongan, dan efektivitas yang terinspirasi, theirness/penghayatan ketuhanan yang di dalamnya kita semua menjadi bagian (Sinetar, dalam Masaong, 2009). Pada tanggal 1112 April 2002, Toko Eksekutif International dari berbagai jenis perusahaan yang mengadakan forum diskusi leadership di Harvard Business School merumuskan lima ciri paham spiritualisme yang dapat membawa keberhasilan seorang CEO, yaitu: (1) integritas atau ke- jujuran; (2) energi atau semangat; (3) inspirasi atau ide dan inisiatif; (4) wisdom atau bijaksana; dan (5) keberanian dalam mengambil keputusan.

Penerapan sistem nilai disiplin, budaya mengarahkan jalan hidup antara pribadi, kelompok (komunitas) dan sifat kultur tidak statis, tetapi menguasai peri-kehidupan secara berkesinambungan pengembangannya (culture is not static but is in a continual state of flux indeed of development) dan mengalami ujian terus-menerus, dievaluasi, dimodifikasi serta perbaikan oleh para anggotanya, baik sebagai individu maupun keseluruhan (Beare, 1992:177). Ciri-ciri kecerdasan spiritual menurut Khavari (Sukidi, 2004) terdiri dari tiga aspek nilai, di antaranya kecerdasan spiritual dipandang dari sudut etika sosial yang dapat menggambarkan tingkat etika sosial seseorang sebagai cermin kadar kualitas kecerdasan spiritual, yaitu: ketaatan kita pada etika dan moral, kejujuran, amanah dan dapat dipercaya, sikap sopan, toleran dan anti kekerasan.

Nabi Muhammad SAW menampilkan nilai kepemimpinan dengan empat unsur, yaitu: (1) fathonah (intelligent); (2) amanah (accountable); (3) siddiq (honest); dan (4) tablig (cooperative). Pendapat lain mengatakan bahwa karakter dasar manusia terdiri dari: dapat dipercaya, rasa hormat dan perhatian, peduli, jujur, tanggung jawab, kewarganegaraan, ketulusan, berani, tekun, disiplin, visioner, adil, dan punya integritas.

Sekolah unggul adalah yang sekolah yang dikembangkan untuk mencapai keunggulan dalam keluaran (output) pendidikannya (Depdikbud, 1994). Untuk mencapai keunggulan tersebut, ma- 
sukan (input), proses pendidikan guru dan tenaga kependidikan, manajemen, layanan pendidikan serta sarana penunjangnya harus diarahkan untuk menunjang tercapainya tujuan tersebut.

Keunggulan sesungguhnya mengacu pada realitas empiris bahwa sekolah tersebut memiliki nilai lebih di antara yang lain yang dasar penilaiannya diserahkan kepada masyarakat (Darmaningtyas 2004:200). Dengan demikian, yang dimaksud dengan sekolah unggul adalah sekolah yang memiliki beberapa kelebihan, baik dari segi input, proses, produk, maupun outcome (kelulusan) dibandingkan dengan sekolah yang lain.

Sekolah dituntut untuk selalu mengikutitrend-global dengan pengenalan kebebasan yang bertanggung jawab, pemberian akses untuk menyampaikan dan berbeda pendapat, serta menghargai keberagaman. Sekolah tidak membatasi ide siswa, kreativitas, dan kebebasan siswa asal dalam batas wajar dan bertanggung jawab. Di SMPN 1 siswa menyampaikan kritik dengan berbagaicara, seperti lewat web sekolah, polling, sampai lewat jejaring sosial di internet. Pernah terjadi siswa menyampaikan keluhan lewat facebook tentang sistem pembelajaran seorang guru di sekolah. Siswa tersebut menulis di facebook dan hal tersebut diketahui oleh guru.

Di sekolah terjadi polemik untuk membenarkan atau menegur siswa tersebut. Akhirnya, disepakati oleh para guru untuk mengingatkan siswa tersebut, apabila ada keluhan agar disampaikan langsung kepada guru yang bersangkutan atau kepada kepala sekolah. School reform sebagaimana di amanatkan dalam UU Sisdiknas No. 20 Tahun
2003, telah diterapkan di ketiga SMP tersebut, sekolah ramah anak, dan sekolah benar-benar tanpa kekerasan sebagai prinsip sekolah modern telah menjadi kultur, aturan sekolah disederhanakan, dan keteladanan diutamakan.

Sistem nilai kesederhanaan dan kesahajaan terakumulasi dalam berbagai kegiatan, di antaranya penjaringan siswa baru (PSB), lewat seleksi objektif, peduli sosial, simpati kepada kesederhanan, mendidik dan mengajarkan pola hidup sederhana, pelarangan memakai $\mathrm{HP}$, perhiasan yg mencolok bagi siswa perempuan, penyediakan fasilitas telpon gratis pada seluruh siswa, dan peduli bencana. Walau berlabel sekolah RSBI, bisa menerima siapa saja asal lulus seleksi. Kalimat asal lulus seleksi berarti pencapaian/prestasi, dan berarti pula ada yang tidak lulus, dan berarti ada persaingan.

Dalam bahasa Inggris, prestasi sering diterjemahkan dengan achievement. Dalam hal ini, terdapattiga unsur, yaitu: siapa yang mencapai (pelaku yang berprestasi); dalam hal apa (objek atau lapangan) berprestasi; dan sejauh mana ia mencapai (kualitas dan standar) pencapaian. Nilai ini termuat dalam tiga hal, yaitu: kinerja (belajar) siswa; kinerja (mengajar)guru; dan kinerja sekolah secara keseluruhan. Prestasi dan persaingan merupakan dua nilai terpisah, namun keduanya dapatdipasangkan. Prestasi diukur dengan standar pencapaian/ulus. Persaingan diukur dengan membandingkan antara prestasi seorang anak dengan anak lain, suatu kelas dengan kelas lain, satu sekolah dengan sekolah lain, satu daerah de- 
ngan daerah lain, dan seterusnya (Mifflen dan Mifflen, dalam Ekosusilo, 2003).

Namun, ada mata rantai yang tersembunyi, yaitu menunjukkan kesederhanaan sekolah dalam penerimaan siswa baru yang menyembunyikan sikap tidak pandang bulu. Sampai batas tertentu, hal tersebut tentu saja tidak dapat diterima karena akan menghambat prestasi seseorang. Selain itu, sebagaimana dikemukakan terdahulu, prestasi dan persaingan itu merupakan suatu konsekwensi (dan bahkan tujuan) dari diciptakannya manusia dengan stratum yang berbeda-beda (Wahab dan Supriadi (ed), 1998).

Sistem nilai kebersamaan dan persaudaraan adalah wujud kehidupan kekeluargaan, persaudaraan saling tolong, tercermin dalam kegiatan, OSIS, PMR, pramuka, keagamaan, silaturahim dan memberikan bantuan kesesama warga yang mengalami kesusahan, budaya kebersamaan, tercermin dalam praktek sehari-hari, sesama/antarsiswa, dan guru, menerapkan kebersamaan, kesetaraan dan merentas keberagaman, nilai kebersamaan, adalah visi sekolah. Aspekaspek yang termasuk hard antara lain adalah struktur organisasi, aturan-aturan, kebijakan, teknologi, dan keuangan. Hal-hal tersebut dapat diukur, dikuantifikasikan serta dikontrol dengan relatif mudah. Hal-hal yang soft adalah yang terkait dengan the human side of organizational (sisi/aspekmanusiawi dari organisasi), meliputinilai-nilai, keyakinan, budaya, serta norma-norma perilaku (Owens. 1995).

Dimensihard, sering disebut pula sebagai the classic elements dari suatu organisasi. Meskipun elemen klasik, se- perti hierarki struktur, formalisasi, dan rasionalisasi itumerupakan hal-hal yang penting, namun hal tersebut tidak dapat sepenuhnya menjelaskan perilaku organisasi (Maslang, dalam Peterson (ed), 1987). Karena dipengaruhi oleh visi dan misi serta tujuan, budaya organisasi bersifat unik. Walaupun organisasi itu sejenis, namun budayanya akan berbeda. Karena itu budaya organisasi disebut juga dengan sifat-sifat internal organisasi yang dapat membedakannya dengan organisasi lain (Siswohartono, 1992).

Sistem nilai agama dalam hal ibadah, tidak terlepas dari esensi ajaran agama tersebut. Kalimat agama berasal daribahasa Sansekerta yang artinya peraturan. Menurut bahasa latin, disebut religion, dalam bahasa Arab disebut Addin. Menurut Durkheim, seorang ahli sosiologi dalam bukunya Gambaran Pertama Kehidupan Keagamaan, disebutkan bahwa agama adalah alam ghaib yang tidak dapat diketahui dan tidak dapat dipikirkan oleh akal manusia sendiri.

MenurutSyekh Mahmud Saltout dalam kitab Al Islam Aqidah wa Syari'ah disebutkan bahwa segala sesuatu yang telah ditentukan oleh Allah terhadap hamba-Nya, meliputi hubungan dengan Tuhan, hubungan sesama muslim, hubungan sesama manusia pada umumnya, hubungan dengan alam sekitarnya. Sistem nilai ibadah di antaranya sebelum pelajaran dimulai diawali dengan kegiatan ibadah, salam, do'a memohon rahmat kepada Tuhan Yang Maha Kuasa agar setiap usaha selalu diberi kesuksesan, diteruskan dengan PBM, pelajaran inti, evaluasi, ditutup do'a, aplikasi keagamaan dan sholat 
jumat atau dhuhur. Namun demikian, sistem ibadah di ketiga SMP tersebut mempunyai karakter sendiri sebagaimana telah disebutkan.

Sinetar (Sukidi, 2004) menafsirkan kecerdasan spiritual sebagai pemikiran yang terilhami. Selanjutnya, dikatakan bahwa kecerdasan spiritual adalah cahaya, ciuman kehidupan yang membangunkan keindahan tidur kita, membangunkan orang-orang dari segala usia dan segala situasi. Kecerdasan spiritual adalah kecerdasan jiwa, yakni tingkat baru kesadaran yang bertumpu pada bagian dalam diri yang berhubungan dengan kearifan di luar ego atau jiwa sadar yang membantu menyembuhkan dan membangun diri manusia secara utuh, yang dengannya manusia tidak hanya mengakui nilai-nilai yang ada, tetapi lebih kreatif menemukan nilainilai baru, juga dapat menyeimbangkan makna dan nilai serta menempatkan kehidupan dalam konteks yang lebih luas.

Ciri-ciri kecerdasan spiritual menurut Khavari (Sukidi, 2004) terdiri atas tiga aspek. Pertama, kecerdasan spiritual dipandang dari sudut spiritual-keagamaan (relasi vertikal manusia dengan Tuhan) yang mencakup: frekuensi do'a, makhluk spiritual, kecintaan pada Tuhan YME yang bersemayam dalam hati, dan rasa syukur ke hadirat-Nya. Kedua, kecerdasan spiritual dipandang dari segi relasi sosial-keagamaan sebagai konsekuensi logis relasi spiritual-keagamaan. Artinya, kecerdasan spiritual harus merefleksikan pada sikap-sikap sosial yang menekankan segi kebersamaan dan kesejahteraan sosial (sosial welfare), yaitu ikatan kekeluargaan an- tarsesama, peka terhadap kesejahteraan orang lain, peka terhadap binatangbinatang, dan sikap dermawan. Ketiga, kecerdasan spiritual dipandang dari sudut etika sosial yang dapat menggambarkan tingkat etika sosial seseorang sebagai cermin kadar kualitas kecerdasan spiritual, yaitu ketaatan kita pada etika dan moral, kejujuran, amanah dan dapat dipercaya, sikap sopan, toleran dan anti kekerasan.

Sistem nilai agama kerendahan hati/ tawaddu' antara lain meletakkan nilai moral pada porsi penentuan kenaikan kelas dan kreteria kelulusan, menghormati dan menyambut siswa di pintu gerbang, diajarkan rendah hati, taat pada pimpinan, tunduk kehendak Tuhan, dibekali training kecerdasan diajarkan tentang makna hidup, supaya mampu menghadapi ujian hidup dengan sabar tawakkal mengembalikan kepada Allah SWT, menghormati yang tua, menyapa secara santun dan jabat tangan telah membudaya. Rendah hati (tawa$\left.d h u^{\prime}\right)$ memiliki konotasi siswa harus menghormat pada guru. Sikap tawadhu' diwujudkan dalam tutur kata dan perilaku baik dihadapan maupun di belakang orang yang dihormati. Sebagai lembaga pendidikan keagamaan yang menjunjung tinggi nilai mengutamakan pendidikan akhlak, budi pekerti, sejenisnya, nilai keteladanan sangat dihargai. Keteladanan ini memiliki dua segi, yaitu keteladanan pihak yayasan kepada para guru, dan keteladanan guru kepada para siswa.

\section{PENUTUP}

Pertama, penerapan sistem nilai pengetahuan. (1) Sistem nilai prestasi: (a) 
visi-misi, RKS terealisir keseluruh PBM; (b) SDM memadai, sarpras cukup dan input selektif; dan (c) PBM kondusif, didukung wali murid, serta komite/yayasan. (2) Sistem nilai mandiri: (a) kebebasan mengembangkan potensi; (b) guru sebagai motivator, \& fasilitator; dan (c) budaya jujur, reward dan sanksi. (3) Sistem nilai disiplin: (a) aturan yang lengkap, mengikat dan disepakati semua pihak; (b) kesadaran untuk melaksanakan aturan tersebut; dan (c) dukungan agama. (4) Sistem nilai keunggulan: (a) unggul merupakan kebutuhan dan tanggung jawab seluruh warga; (b) belajar intensip, terutama mapel mipa dan bahasa; (c) sejarah positip sekolah; dan (d) paket aplikasi sekolah (PAS).

Kedua, penerapan sistem nilai sosial. (1) Sistem nilai kebebasan: (a) adanya kebebasan; (b) polling; dan (c) menghargai keberagaman. (2) Kesederhanaan dan kesahajaan: (a) PSB seleksi objektif; (b) peduli sosial, simpati dan mengajarkan hidup sederhana; (c) pelarangan memakai HP, serta perhiasan menyolok bagi siswa perempuan. (3) Sistem nilai kebersamaan dan persaudaraan: (a) sikap saling tolong membudaya di seluruh kegiatan; (b) terjalin rasa saling menghormati, dan menyayangi; dan (c) kesetaraan, keberagaman dan kebersamaan.

Ketiga, penerapan sistem nilai agama. (1) sistem nilai ibadah: (a) pelajaran didahului ibadah; (b) salam, dan do'a, agar setiap usaha mendapat rahmat; (c) PBM, pelajaran inti, evaluasi, diakhiri do'a dan salam; (d) ibadah meningkatkan keimanan dan ketaqwaan. (2) Sistem nilai kerendahan hati/tawaddu': (a) meletakkan nilai moral pada porsi penentuan kenaikan kelas dan kriteria kelulusan; (b) penghormatan siswa; (c) taqwa, jabat tangan, taat pada pimpinan, dan tunduk kehendak Tuhan, menjadikan siswa santun dan rendah hati; dan (d) dibekali training kecerdasan, diajarkan hakikatdan makna hidup, iman, akhlak, rendah hati, sabar, dan tawakkal.

\section{UCAPAN TERIMA KASIH}

Ucapan terima masih disampaikan kepada berbagai pihak yang telah berkontribusi terhadap penelitian yang dilakukan, khususnya pihak sponsor yang telah mendanai penelitian ini. Selain itu, ucapan terima kasih juga disampaikan kepada sejawat yang telah membantu dan seluruh subjek penelitian, khususnya dari ketiga SMP yang dijadikan tempat penelitian, serta berbagai pihak lain yang tidak dapat disebutkan satu per satu atas berbagai masukan dan sumbang sarannya. Semoga semua itu menjadi amal ibadah yang diterima Allah SWT. Amin.

\section{DAFTAR PUSTAKA}

Alam, S. 2006. "Pengaruh Akuntabilitas Berimbang pada Kualitas Pendidikan. Suatu Kajian". Buletin PUSPENDIK, No. 8 - 17 Juli 2006: p.3-6. Jakarta: Pusat Penilaian Pendidikan Depdiknas.

Alisjahbana, S.T. 1986. Antropologi Baru: Nilai-Nilai sebagai Tenaga Integrasi dalam Pribadi, Masyarakat dan Kebudayaan. Jakarta: Dian Rakyat.

Beare, H. Brian J.C. and Ross H. Millikan. 1992. Creating an Excellent School. London and New York: 
Biddles Lid, Guildford and King's Linn.

Darmaningtyas. 2004. Pendidikan Yang Memiskinkan. Yogyakarta: Galang Press.

Depdikbud, 1994. Pengembangan Sekolah Unggul. Jakarta. Dirjen Dikdasmen.

Ekosusila, M. 2003. Sekolah Unggul Berbasis Nilai, Studi Multi Kasus di SMAN 1, SMA Regina Pacis, SMA Al Islam 01 Surakarta. Unifet: Bantara Press.

Ivancevich, J.M., Konopaske, R., Matteson, M.T. 2005. Perilaku dan Manajemen Organisasi Jilid 1. Jakarta: Erlangga.

Kadarusmadi. 1996. “Upaya Orang Tua dalam Menata Situasi Pendidikan dalam Keluarga". Disertasi, Tidak Dipublikasikan Bandung PPS. IKIP Bandung.

Kaswardi, E.M. 1993. Pendidikan Nilai Memasuki Tahun 2000. Jakarta: Gramedia.

Masaong, A.K. 2008. "Hubungan Kecerdasan Intelektual, Kecerdasan Emosional, Kecerdasan Spiritual, Gaya Kepemimpinan Kepala Sekolah dan Iklim Sekolah dengan Kinerja Sekolah pada Pendidikan Menengah di Kota Gorontalo". Disertasi, Program Studi Manajemen Pendidikan, Program Pascasarjana, Universitas Negeri Malang.
Madjid. N. 1992. Islam. Doktrin dan Peradaban. Jakarta: Yayasan Wakaf Paramadina.

Owens. R.G. 1995. Organisational Behavior in Education. Boston Allyn and Bacon.

Peterson. M.W. (ed). 1987.Organistional and Governance in Higher Education (3 rd) Lexington. Massacheets: Ginn Press.

Sinarmo, H.J. 1998. "Menciptakan VisMisi Motivatif (In Search of Powerfull)". Majalah Manajemen. Agustus. Jakarta.

Siswohartono, J. 1992. "Studi tentang Kultur Oranisasi Universitas Harapan Negara". Disertasi, Tidak di Publikaskan.PPS IKIP Malang.

Sutarmadi. A. 1997. Keluarga Sakinah. Jakarta: Departemen Agama.

Suryadi. A.1998. "Permasalahan dan Tantangan Pembangunan Pendidikan". Jurnal Mimbar Pendidikan. Tahun XVII (4): 17-28.

Sukidi, 2004. Kecerdasan Spiritual; Mengapa SQ Lebih Penting daripada IQ dan EQ. Jakarta: Gramedia Pustaka Utama.

Siagian, S.P. 1989. Teori Motivasi dan aplikasi, Jakarta : Rineke Cipta.

Wahab, WW. \& D. Supriadi. (ed). 1998. On Publik and Privat School: Which One Is Better?. Bandung, PPS IKIP Bandung. 